\title{
KAJIAN POPULASI Tyto alba PADA PERKEBUNAN KELAPA SAWIT RAKYAT DI KABUPATEN KUANTAN SINGINGI
}

\author{
Seprido $^{1)}$, Desta Andriani ${ }^{2)}$ \\ ${ }^{1), 2)}$ Program Studi Agroteknologi Universitas Islam Kuantan Singingi \\ email $^{l)}$ : sepridhopiliang@ymail.com \\ email $^{2}$ : andrianifito@gmail.com
}

\begin{abstract}
ABSTRAK: Kajian populasi Tyto alba pada perkebunan kelapa sawit rakyat di kabupaten Kuantan Singingiini dilakukan selama 4 bulan dari bulan juni hingga September 2020 di perkebunan kelapa sawit rakyat di Kabupaten Kuantan Singingi. lokasi pengamatan diletakkan pada 7 stasiun penelitian. Metode yang digunakan dalam penelitian ini adalah survey lapangan yang terdiri dari tiga tahapan yaitu Pra analisis untuk pengumpulan data sekunder dari kepustakaan dan penelusuran di internet; Analisis yang dilakukan dengan pelaksanaan kunjungan lapangan di perkebunan kelapa sawit rakyat di Kabupaten Kuantan Singingi serta wawwancara dengan pemilik kebun; serta pengumpulan berupa hasil kunjungan lapangan dan data sekunder dianalisis dan dilakukan pengevaluasian guna mendapatkan kesimpulan. Dari hasil penelitian yang dilakukan, didapatkan sebanyak 28 individu Tyto alba yang terdiri dari 15 individu jantan dan 13 individu betina dengan rasio perbandingan kelamin 1. 15 .
\end{abstract}

Kata Kunci: Tyto alba, Kelapa Sawit, Hama, Tikus

\begin{abstract}
The study of the Tyto alba population on smallholder oil palm plantations in Kuantan Singingiini district was carried out for 4 months from June to September 2020 in smallholder oil palm plantations in Kuantan Singingi Regency. the observation location is placed at 7 research stations. The method used in this research is a field survey which consists of three stages, namely preanalysis for collecting secondary data from literature and searching the internet; The analysis was carried out by conducting field visits to smallholder oil palm plantations in Kuantan Singingi Regency and interviews with plantation owners; and collection in the form of results of field visits and secondary data analyzed and evaluated in order to obtain conclusions. From the results of the research conducted, there were 28 Tyto alba individuals consisting of 15 males and 13 females with a sex ratio of 1.15 .
\end{abstract}

Keywords: Tyto alba, Palm Oil, Pests, Rats

\section{PENDAhULUAN}

Kelapa sawit merupakan salah satu komoditi utama bidang pertanian yang menopang perekonomian masyarakat. Hingga saat ini, komoditi kelapa sawit terus dilakukan pengembangannya. Salah satu hambatan yang dihadapi dalam pengembangan ini adalah adanya serangan hama terutama tikus.

Tikus merupakan hewan liar yang sangat mudah untuk beradaptasi. Di sektor pertanian, tikus sering kali menjadi ancaman dalam praktek budidayanya. Bahkan bisa menimbulkan kerugian hingga mencapai 5 ton/ha/tahunnya (Dhamayanti, 2009). Pengendalian hama tikus ini cendering diabaikan pada perkebunan kelapa sawit rakyat, akan tetapi pada perkebunan kelapa sawit besar swasta sudah cenderung dilakukan secara sistematis. Bahkan sudah banyak yang menggunakan biopredatornya, salah 
satunya adalah Tyto alba(Seprido \& Mashadi, 2019).

Tyto albamerupakan biopredator yang mampu memberikan hasil yang baik dalam pengendalian hama tikus ini, selain ramah lingkungan jenis ini juga tidak bersifat migratory dan juga memiliki kemampuan daya jelajah sekitar 1.6 hingga $5.6 \mathrm{~km}$ di sekitar sarang, bahkan hingga $12 \mathrm{~km}$ jika hewan mangsa berkurang disekitar sarangnya (Agustini, 2013).

Beberapa kelebihan Tyto albaini sebagai predator tikus adalah memiliki kemampuan pendeteksian mangsa dari jarak jauh yang cukup baik, mampu terbang cepat dan menyergap tanpa suara, memiliki pendengaran yang sangat tajam serta memiliki jenis mangsa yang spesifik yaitu tikus. Bahkan dalam membunuh atau mengkonsumsi tikus, Tyto albadewasa mampu memangsa 2 hingga 5 ekor tikus per harinya (Agustini, 2013).

Beberapa keuntungan penggunaan Tyto albadalam pengendalian tikus adalah; sangat efektif dalam menekan populasi tikus; sangat efisien dari sisi waktu pengendalian; dan tidak membutuhkan tenaga dan biaya yang besar.

Tyto albamerupakan jenis yang tidak umum dijumpai di Kalimantan dan dataran rendah di pulau sumatera, akan tetapi sangat tersebar di sumatera bagian tengah dan sumatera selatan (MacKinnon et al, 2000). Tyto albamenyukai lubang pohon atau lubang di tebing atau areal yang memiliki vegetasi alami disekitarnya (Shawyer, 2011).

Untuk upaya optimalisasi pengendalian hama tikus di perkebunan kelapa sawit rakyat di kabupaten kuantan singingi perlu adanya kajian populasi Tyto albasebagai biopredator tikus di perkebunan kelapa sawit rakyat di Kabupaten Kuantan Singingi.

Tabel 1. Deskripsi dan Vegetasi sekitar Stasiun Penelitian

\section{METODE PENELITIAN}

Penelitian tentang kajian populasi Tyto albadi perkebunan kelapa sawit rakyat di Kabupaten Kuantan Singingi ini dilakukan di 7 Kecamatan yang ada di kaupaten Kuantan Singingi dari bulan Juni hingga September 2020. Pelaksanaan penelitian ini terbagi menjadi 3 tahap survey yaitu : 1 . Tahap Pra analisis yang bertujuan untuk pengumpulan data sekunder dari kepustakaan dan penelusuran di internet; 2. Analisis yang dilakukan dengan pelaksanaan kunjungan lapangan di perkebunan kelapa sawit rakyat di Kabupaten Kuantan Singingi serta wawwancara dengan pemilik kebun; 3 . Tahapan pengumpulan berupa hasil kunjungan lapangan dan data sekunde dianalisis dan dilakukan pengevaluasian guna mendapatkan kesimpulan.

Pengambilan data di lapangan dilakukan dengan cara mengunjungi perkebunan kelapa sawit rakyat pada masing masing lokasi yang telah ditetapkan. Pelaksanaan survey lapangan ini dilakukan dari pukul 18.00 - 21.00 WIB dengan menelusuri perkebunan kelapa sawit rakyat tersebut. Data yang didapatkan disajikan dalam bentuk tabel dan diolah secara deskriptif.

\section{HASIL DAN PEMBAHASAN Gambaran Umum Lokasi Penelitian}

Lokasi penelitian adalah perkebunan kelapa sawit rakyat yang terletak dalam satu hamparan dengan luasan minimal 10 ha. Dalam penelitian ini terdapat 7 stasiun pengamatan yang masing masingnya memiliki total luasan dan kepemilikan perkebunan kelapa sawit yang berbeda (Tabel 1.)

\begin{tabular}{|l|l|l|l|l|l|}
\hline No & Stasiun & Kecamatan & $\begin{array}{l}\text { Luas } \\
\text { (ha) }\end{array}$ & $\begin{array}{l}\text { Vegetasi Dibawah } \\
\text { Tegakkan }\end{array}$ & Berbatasan \\
\hline 1 & 1 & Pucuk Rantau & 35 & Semak, Pakis resam, & Hutan sekunder, perkebunan \\
\hline
\end{tabular}




\begin{tabular}{|l|l|l|l|l|l|}
\hline 2 & 2 & & & & karet, pemukiman \\
\hline 3 & 3 & Hulu Kuantan & 18 & Semak, Pakis resam & $\begin{array}{l}\text { Perkebunan karet, semak } \\
\text { hutan sekunder } \\
\text { belukar, pemukiman } \\
\text { masyarakat }\end{array}$ \\
\hline 4 & 4 & Gunung Toar & 28 & Pakis resam, semak belukar & $\begin{array}{l}\text { Semak belukar, hutan } \\
\text { sekunder }\end{array}$ \\
\hline 5 & 5 & Sentajo Raya & 16 & Semak, pakis resam & Sungai, semak belukar \\
\hline 6 & 6 & Kuantan Tengah & 32 & Semak & $\begin{array}{l}\text { Pemukiman masyarakat dan } \\
\text { semak belukar }\end{array}$ \\
\hline 7 & 7 & Benai & 15 & Semak & $\begin{array}{l}\text { Pemukiman masyarakat dan } \\
\text { semak belukar }\end{array}$ \\
\hline
\end{tabular}

Pada umumnya, vegetasi sekitar yang terdapat di sekitar lokasi penelitian adalah berupa perkebunan karet, pemukiman masyarakat, serta hutan sekunder. Pada stasiun 1 vegetasi sekitar berupa hutan sekunder yang didominasi oleh semak belukar, perkebunan karet campuran serta adanya pemukiman masyarakat. Pada stasiun 2 vegetasi sekitar berupa perkebunan karet campuran, terdapatnya rawa dan hutan sekunder. Pada stasiun 3 vegteasi sekitar perkebunan karet, semak belukar dan pemukiman masyarakat. Padas stasiun 4, vegetasi sekitarnya berupa semak belukar dan hutan sekunder. Pada stasiun 5 berbatasan dengan sungai dan semak belukar. Pada stasiun 6 ,

\section{Populasi Tyto alba}

Dari pelaksanaan survey lapangan dengan total luas lahan 167 ha dan waktu kunjungan 10 hari pengamatan dijumpai sebanyak 28 individu Tyto albadi perkebunan kelapa sawit rakyat di Kabupaten Kuantan Singingi (Tabel 2.).

Tabel 2. Jumlah individu Tyto albapada perkebunan kelapa sawit rakyat di kabupaten Kuantan Singingi

\begin{tabular}{|l|l|l|l|l|l|}
\hline No & Stasiun & TH & LL & JI & KP \\
\hline 1 & 1 & 10 & 35 & 4 & 0.114 \\
\hline 2 & 2 & 10 & 23 & 7 & 0.304 \\
\hline 3 & 3 & 10 & 18 & 2 & 0.111 \\
\hline 4 & 4 & 10 & 28 & 6 & 0.214 \\
\hline 5 & 5 & 10 & 16 & 3 & 0.187 \\
\hline 6 & 6 & 10 & 32 & 4 & 0.125 \\
\hline 7 & 7 & 10 & 15 & 1 & 0.067 \\
\hline & TOTAL & 70 & 167 & 28 & 0.167 \\
\hline
\end{tabular}

Ket : TH (total Hari Pengamatan); LL (Luasan Lahan); JI (jumlah Individu); KP (Kepadatan Populasi)

Rata rata jumlah individu Tyto alba perlokasi penelitian adalah sebanyak 4 ekor dengan jumlah individu tertinggi dijumpai pada stasiun 2 dengan jumlah individu 7 ekor, kemudian diikuti oleh stasiun 4 dengan jumlah individu sebanyak 6 ekor, stasiun 1 dan 6 dengan jumlah individu masing masingnya 4 ekor. Kemudian diikuti oleh stasiun 5 dengan jumlah individu sebanyak 3 ekor, dan dilanjutkan oleh stasiun 3 dan 7 dengan masing masing jumlah individunya adalah 2 dan 1 ekor.

Tyto alba merupakan karnivora nokturnal yang akrab dengan kehidupan manusia dan sering mendiami areal perbatasan hutan dengan areal pertanian bahkan juga di areal pemukiman masyarakat bahkan di kampus Universitas Padjajaran terdapat populasi Tyto albayang mendiami gedung kampus kurang dari 5 individu degan rata rata okupasi gedung 0,24 dan jumlah sarang rata rata 1.16 per gedung (Partasasmita, Muhammad, \& Iskandar, 2015). Sedangkan diperkebunan kelapa sawit PT. Tri Bakti Sarimas dijumpai sebanyak 171 individu Tyto alba(Seprido \& Mashadi, 2019).

Tyto alba merupakan salah satu jenis predator penting bagi tikus. Disebabkan jenis ini tidak membuat sarang sendiri maka mereka memanfaatkan tempat tempat tersembunyi untuk huniannya seperti di atas plafon bangunan $(76,41 \%)$, pohon $(20,75 \%)$ dan gupon $(2,84 \%)$ pada persawahan

$(\mathrm{K}$,

Soeprapto 
Mangoendihardjo F.X, \& Djuwantao, 2004). Pada daerah beriklim sedang, panas dapat merusak perkembangbiakan Tyto albadan curah hujan sangat berperan penting dalam pekembangan vegetasi dan akhirnya menyebabkan melimpahnya mamalia kecil terutama tikus sebagai mangsa Tyto alba(Charter et al., 2017).

Jenis ini merupakan jenis burung penetap dengan masa reproduksi mencapai 6 tahun 2 bulan. jenis ini bisa ditemukan pada bebagai habitat terutama pada dataran rendah dengan dan tanpa pohon, lahan pertanian, desa dan perkotaan, persawahan, perkebunan kelapa sawit, pertanaman tebu, tebing berbatu (Birdlife, 2019).

\section{Rasio kelamin Tyto alba}

Secara umum populasi Tyto albateramati didominasi oleh jenis kelamin jantan (15 individu) sedangkan jenis kelamin betina hanya teramati 13 individu. Jenis kelamin jantan juga mendominasi dijumpai pada stasiun 5 dan 7. Sedangkan berdasarka stasiun penelitian jenis kelamin betina mendominasi pada stasiun 2, sedangkan pada stasiunnya termatai jumlah individu jberdasarkan jenis kelaminnya sama. (Tabel 3.)

Tabel 3. Ratio kelamin Tyto albapada Perkebunan Kelapa Sawit Rakyat di Kabupaten Kuantan SIngingi

\begin{tabular}{|l|l|l|l|l|l|}
\hline \multirow{2}{*}{ No } & \multirow{2}{*}{ Stasiun } & \multicolumn{2}{|c|}{ Jumlah } & \multirow{2}{*}{ JI } & Ratio \\
\cline { 3 - 5 } & & Jantan & Betina & & \\
\hline 1 & 1 & 2 & 2 & 4 & 1 \\
\hline 2 & 2 & 3 & 4 & 7 & 0.75 \\
\hline 3 & 3 & 1 & 1 & 2 & 1 \\
\hline 4 & 4 & 3 & 3 & 6 & 1 \\
\hline 5 & 5 & 2 & 1 & 3 & 2 \\
\hline 6 & 6 & 2 & 2 & 4 & 1 \\
\hline 7 & 7 & 1 & - & 1 & 1 \\
\hline & TOTAL & 15 & 13 & 28 & 1.15 \\
\hline
\end{tabular}

Dari Tabel 3. diketahui bahwa rasio jenis kelamin secara umum memiliki nilai sebesar 1.15, ini berarti bahwa total individu jenis kelamin jantan lebih banyak dijumpai diandingkan dengan jumlah individu berjenis kelmin betina.

Pada stasiun 1, stasiun 3, stasiun 4 dan stasiun 6 dijumpai jumlah individu jantan dan betina yang sama yaitu berturut turut 2 , 1, 3 dan 2. Sedangkan pada stasiun 2, jumlah individu jantan lebih sedikit (3 ekor) dijumpai dibandingkan dengan individu betina. Bertolak belakang dengan stasiun 5 dan 7 , yang lebih didominasi oleh individu berjenis kelamin jantan.

Tyto alba merupakan yang tersebar hampir diseluruh dunia. Jenis ini memiliki tubuh besar dengan bulu leher depan berwarna kuning berbintik hitam pada individu betina dan berwarna putih dan berbintik hitam pada individu jantan (Sukmawati, Siti, \& Candrakasih, 2017).

\section{KESIMPULAN}

Berdasarkan hasil penelitian tentang Kajian populasi Tyto alba pada perkebunan kelapa sawit rakyat di kabupaten kuantan singingi dijumpai sebanyak 28 individu Tyto alba yang dengan jenis kelamin jantan sebanyak 15 individu dan jenis kelamin betina sebanyak 13 individu.

\section{DAFTAR PUSTAKA}

Agustini, S. (2013). Burung hantu pengendali tikus secara hayati. Buletin Inovasi Teknologi Pertanian, 1(November), 48-50.

Birdlife, I. (2019). Tyto alba,. The IUCN REdlist of Threatened Species 2019: E.T22688504A155542941, 8235. https://doi.org/http://dx.doi.org/10.230 5/IUCN.UK.20193.RLTS.T22688504A155542941.en Copyright:

Charter, M., Izhaki, I., Meyrom, K., Aviel, S., Leshem, Y., \& Roulin, A. (2017). The relationship between weather and reproduction of the Barn Owl Tyto alba in a semi-arid agricultural 
landscape in Israel The relationship between weather and reproduction of the Barn Owl Tyto alba in a semi-arid agricultural landscape in Israel, (March 2018). https://doi.org/10.3184/175815617X15 063340995365

Dhamayanti, A. (2009). Kajian sosial ekonomi.pdf. In Seminar Nasional Perlindungan Tanaman (pp. 439-445). Bogor: Pusat Kajia Pengendalian Hama Terpadu Departemen Proteksi Tanaman Fakultas Pertanian Institut Pertanian Bogor. Retrieved from http://repository.ipb.ac.id/handle/1234 56789/54330

K, R. A., Soeprapto Mangoendihardjo F.X, W., \& Djuwantao. (2004). Tipe hunian dan Jenis Mangsa Burung Serak Tyto Alba javanica pada ekosistem persawahan.pdf. Jurnal Perlindungan Tanaman Indinesia, 97-105.

Partasasmita, R., Muhammad, G. I., \& Iskandar, J. (2015). Populasi, okupasi dan pengetahuan masyarakat tentang burung Serak Jawa (Tyto alba javanica J.F. Gmelin 1788) di Kawasan Kampus Universitas Padjadjaran Jatinangor, Kabupaten Sumedang, 1, 1570-1576.

https://doi.org/10.13057/psnmbi/m010 705

Seprido, \& Mashadi. (2019). Pemanfaatan Tyto alba sebagai pengendali hama tikus di perkebunan kelapa sawit di kabupaten kuantan singingi. Jurnal Ilmiah Pertanian, 16(1), 1-7.

Shawyer, C. R. (2011). Barn Owl Tyto alba Survey Methodology and Techniques for use in Ecological Assessment: Developing Best Practice in Survey and Reporting. Winchester: IEEM.

Sukmawati, N. M. S., Siti, N. W., \& Candrakasih, N. N. (2017). Pengembangan Burung Hantu ( Tyto alba ) Sebagai Pengendali Hama Tikus di Desa Babahan, 16(1), 92-98. 